\title{
ФОРМУВАННЯ КОМПЕТЕНТНОСТІ МЕДИЧНИХ СЕСТЕР
}

\author{
А. Е. Литвинова \\ ДВНз «Тернопільський державний медичний університет \\ імені І. Я. Горбачевського МОЗ Украӥни»
}

\begin{abstract}
У зв’язку з швидким темпом розвитку медичної галузі постає питання відповідності рівня компетентності медичних працівників. Тому оптимізація методів навчання фахівців на основі компетентнісного підходу займає значне місце у системі викладання. Зокрема, студенти освоюють дисципліну «Сестринська етика та деонтологія», яка включає теми професійної поведінки медсестри, взаємозв’язок медичного персоналу, етичні та деонтологічні проблеми сучасної медичної науки, сучасні проблеми медичної етики та деонтології.
\end{abstract}

\section{FORMATION OF THE COMPETENCE OF NURSES}

\section{A. E. Lytvynova}

\section{Horbachevsky Ternopil State Medical University}

The rapid development of medical industry in the field of the medical care demands to improve the professional competence level among medical staff. Therefore, the optimization of training methods on the basis of competence approach for nursing specialists is important task today. For this aim students master the discipline «Nursing Ethics and Deontology", which includes topics on the professional behavior of the nurse, the relationship of medical staff, ethical and deontological problems of modern medical science, modern problems of medical ethics and deontology.

Вступ. Євроінтеграція української медицини призводить до змін у сталій системі надання допомоги. Внаслідок високих темпів розвитку медичної реформи виникає потреба у підвищенні рівня компетентності молодшого медичного персоналу. Питання компетентності наразі підлягає обговоренням та пошукам найефективнішої системи навчання фахівців.

Проблемами формування компетентності у майбутніх медичних сестер наразі активно займається надзвичайно велика кількість науковців (Дж. Равен, А. В. Хуторський, Н. М. Болюбаш, І. О. Зимня). Але велика кількість питань щодо сутності, структури та особливостей професійної компетентності залишаються відкритими.

Основна частина. При аналізі навчальної літератури було виявлено, що дослідження щодо компетентності молодших медичних працівників перебуває на стадії активного розвитку та охоплює багато аспектів.

Також стало зрозуміло, що значення «компетенція» та «компетентність» не викликають у науковців єдиної точки зору. Так, наприклад, Дж. Равен означував (с) А. Е. Литвинова, 2017 компетентність як специфічну здатність, необхідну для ефективного виконання конкретної дії в конкретній предметній галузі, яка включає вузькоспеціальні знання, особливого роду предметні навички, способи мислення, а також розуміння відповідальності за свої дії. Бути компетентним - значить мати набір специфічних компетентностей різного рівня [1]. Дж. Равен у своїх працях ці два терміни висвітлює як синоніми, коли в той самий час інші науковці чітко розмежовують ці поняття. Н. М. Болюбаш вважає, що у окремих дослідженнях складові професійної компетентності називають: «компоненти», «компетенції», «ключові (базові) компетенції», «основні компетенції». Зроблений аналіз дозволяє стверджувати, що на сьогодні у педагогічній науці немає чіткого уявлення про співвідношення і структуру понять «компетентність» та «компетенція». Ми не будемо їх ототожнювати та вважатимемо, що між ними існує наступний зв'язок (А. В. Хуторський) [2]:

- компетенція - сукупність взаємопов'язаних якостей особистості (знань, умінь, навичок, способів діяльності), що єзаданими до відповідного кола предметів 
і процесів та необхідними для якісної продуктивної дії стосовно них;

- компетентність - володіння людиною комплексом відповідних компетенцій, що включає їі особистісне ставлення до них та предмета діяльності [3].

На прикладі комунальної установи «Бериславський медичний коледж» Херсонської обласної ради хочу продемонструвати методи розвитку в студентів медсестринства таких складових компетентності, як:

- особистісно-індивідуальна компетентність сукупність компетенцій, що відображають професійно спрямовані переконання, цінності, потреби, вольові риси особистості, мотиви професійної діяльності, уміння досягати поставленої мети при виконанні професійних завдань [4]. При наявності такої складової медична сестра повинна володіти такими етичними елементами, як цінності (професіоналізм, здоров'я, здорове навколишнє середовище, незалежність, людська гідність, турбота) та чесноти (знання, вміння, співпереживання, милосердя, терпіння, цілеспрямованість). Дані цінності прищеплюють студентам під час викладання дисциплін «Основи медсестринства», «Медсестринство в геріатрії та геронтології»;

- предметно-практична компетентність - компетенції, що включають систему фундаментальних знань класичних наук, соціально-економічних законів та теорій, сутності, структури і тенденцій розвитку економічних систем; методів економічного аналізу господарських процесів на мікро- та макрорівнях, методів прийняття рішень [4]. Фахівець має володіти в достатньому обсязі знаннями з різних клінічних дисциплін, згідно з програмами Міністерства охорони здоров'я України, нормативно-правовою базою, галузевими стандартами та практичними навичками, які входять в перелік функціональних обов'язків медичної сестри. Ці компетенції формуються у студентів на заняттях із дисципліни «Основи права» з курсу лекторіїв, які включають такі теми: обов'язки медичних працівників, захист прав пацієнта, цивільно-правовий статус медичного працівника, кримінальна відповідальність в охороні здоров'я, загальна тривалість яких 12 академічних годин.

- інформаційна компетентність - компетенції, що містять систему знань та вмінь за допомогою наявних засобів інформаційних технологій самостійно проводити пошук, аналіз, відбір, обробку та передачу необхідної інформації. Освітній процес наразі передбачає близько 50 \% самостійного опрацювання навчальної інформації. Студенти коледжу здійснюють самостій- ний пошук та опрацювання інформації, а викладач на заняттях аналізує якість засвоєння знань та корегує їх;

- управлінська компетентність - сукупність компетенцій, що включають систему знань основ теорії управління; розвиненість умінь планування, формування цілей та завдань діяльності, організації діяльності, аналізу результатів діяльності, виокремлення та формулювання проблемних аспектів професійної діяльності, впровадження прогресивних форм і методів професійної діяльності [4]. Ця складова є надзвичайно важливим елементом, адже під час виконання медсестринського процесу використовують такі форми діяльності, як оцінка стану, постановка мети, планування втручань, оцінка ефективності втручань;

- пізнавальна компетентність - інформаційні компетенції, які відображають систему знань та вмінь пізнавальної діяльності; розвиненість умінь цілепокладання, самостійної навчально-пізнавальної діяльності, самооцінки. Система вмінь створення, опанування і використання інновацій у професійній діяльності [4]. 3 цією метою керівництвом закладів охорони здоров'я здійснюється організація підвищення рівня кваліфікації медичних працівників за допомогою курсів, семінарів, інформаційних компаній. На території Бериславського медичного коледжу функціонує база відділення післядипломної освіти, яка проводить курси підвищення кваліфікації з 10 спеціалізацій. Загальна кількість учасників курсів - 350 чоловік на рік. Кількість академічних годин підготовки - 144;

- комунікативна компетентність - система знань та умінь взаємодії з оточуючими людьми, розвиненість умінь професійного спілкування та роботи в групі [4]. Для розвитку цієї складової використовують опанування студентами дисципліни «Медсестринська етика та деонтологія», яка включає теми з професійної поведінки медичної сестри, взаємовідносини медичних працівників, етичні та деонтологічні проблеми сучасної медичної науки, сучасні проблеми медичної етики та деонтології. Загальна тривалість курсу 54 год, 24 з яких виділяють на самостійне опрацювання.

Висновки. На якість компетентності молодшого медичного персоналу впливає надзвичайно велика кількість чинників. Залежно від наявності всіх складових компетентності залежить рівень надання допомоги пацієнтам. Під час розвитку медицини постає питання щодо налагодження методів навчання фахівців. Тому що саме від рівня освіченості та компетентності з різних питань молодшого медичного персоналу залежить кінцевий результат лікування. 


\section{СПИСОК ЛІТЕРАТУРИ}

1. Равен Дж. Педагогическое тестирование: проблемы, заблуждения, перспективы ; пер. с англ. / Дж. Равен. - 2-е изд., испр. - М. : «Когито-Центр», 2001. - 142 с.

2. Болюбаш Н. М. Теоретичні засади формування професійної компетентності майбутніх економістів / Н. М. Болюбаш // Наукові праці. - Т. 112.

3. Хуторский А. В. Ключевые компетенции как компонент личностно-ориентированного образования /
А. В. Хуторский // Народное образование. - 2003. № 2. - С. 55-60.

4. Зимняя И. А. Ключевые компетентности как результативно-целевая основа компетентностного подхода в образовании. Авторская версия / И. А. Зимняя. - М. : Исследовательский центр проблем качества подготовки специалистов, 2004. - 42 с. 